\title{
Observation Of Uterine Involution In Etawa Crossbreed Goats (Capra hircus) Using Transcutaneus Ultrasonography
}

\section{Observasi Involusi Uterus pada Kambing Peranakan Etawa (Capra hircus) Menggunakan Ultrasonografi (USG) Transkutaneus}

\author{
Juli Melia ${ }^{1}$, Ayu Wannisa ${ }^{2}$, Tongku Nizwan Siregar ${ }^{1}$, Hafizuddin $^{1}$, Budianto Panjaitan ${ }^{3 *}$, Arman Sayuti $^{3}$, Syafruddin $^{3}$ \\ ${ }^{1}$ Reproduction Laboratory of Veterinary Medicine, Universitas Syiah Kuala, Banda Aceh \\ ${ }^{2}$ Study Program of Veterinary Medicine, Universitas Syiah Kuala, Banda Aceh \\ ${ }^{3}$ Clinic Laboratory of Veterinary Medicine, Universitas Syiah Kuala, Banda Aceh \\ *Corresponding Author, Email: budi@unsyiah.ac.id
}

Naskah diterima: 8 April 2019, direvisi: 20 Juli 2020, disetujui: 20 Nopember 2020

\begin{abstract}
Abstrak
Tujuan penelitian ini adalah untuk mengamati involusi uterus kambing Peranakan Etawa (PE) dengan menggunakan ultrasonografi (USG) secara transkutaneus. Penelitian ini menggunakan empat ekor kambing PE betina pasca melahirkan yang proses pengeluaran plasenta terjadi secara normal. Kambing PE diperiksa pada posisi berbaring secara menyamping. Involusi uterus diamati setiap hari. Penelitian dimulai dari hari pertama pasca melahirkan sampai tidak ada lagi pengurangan diameter lumen pada cornu uteri. Dari hari ke-1 hingga ke-7 periode pasca melahirkan, pencitraan ultrasonografi pada dinding uterus menunjukkan karunke yang terlihat hipoechoik, lumen uterus terisi lokia (gambar terlihat hipoechoik sampai anechoik) dan lumen pada cornu uteri terlihat dengan jelas yang telah berkurang diameternya dari 105,9 $\pm 0,9 \mathrm{~mm}$ menjadi $87,2 \pm 4,6 \mathrm{~mm}$. Mulai hari ke- 8 sampai ke-14, diameter lumen mengalami penurunan dari 80,4 $\pm 3,8 \mathrm{~mm}$ menjadi 63,6 $\pm 3,2 \mathrm{~mm}$. keberadaan karunkel berkurang dan jumlah lokia berkurang (anechoic). Mulai hari ke-15 sampai ke-21, diameter lumen mengalami penurunan dari $61,4 \pm 2,1 \mathrm{~mm}$ menjadi $52,1 \pm 2,7 \mathrm{~mm}$, dan sisa-sisa karunkel dan lokia masih dapat terlihat. Mulai hari ke-22 sampai ke-26, diameter dinding rahim telah menurun dari 49,7 $\pm 0,6 \mathrm{~mm}$ menjadi 41,5 $\pm 6,7 \mathrm{~mm}$, lokia dan karunkel sudah tidak terlihat lagi. Pada hari ke-26 sampai ke-30, diameter lumen conu uteri masih mengalami penurunan dari 41,5 $\pm 6,7 \mathrm{~mm}$ menjadi 31,7 $\pm 0,9$ $\mathrm{mm}$. Ukuran diameter lumen cornu uteri mengalami penurunan setiap hari dan menjadi stabil pada hari ke-30, dan berkurang pada hari ke-31, namun ukuran diameter lumen masih sama seperti pada hari ke30 pasca melahirkan $(31,7 \pm 0,9 \mathrm{~mm})$. Oleh karena itu dapat disimpulkan bahwa lama involusi uterus pada kambing PE pasca melahirkan secara normal adalah 30-31 hari.
\end{abstract}

Kata kunci: Kambing PE; ultrasonografi; involusi uterus

\begin{abstract}
The aim of this study was to observe the uterine involution of Etawa crossbreed goats using transcutaneous ultrasonography (USG). This study used four postpartum female goats that released placenta normally. The goats were examined on lateral recumbence position. Uterine involution was observed daily. The study began from the first day of postpartum period until there were no more reduction of uterine horns lumen diameter. From the $1^{\text {st }}$ to $7^{\text {th }}$ day of postpartum period, ultrasound imaging of the uterine wall showed caruncle which was hypoechoic, lumen of uterine filled with lochia (the image was hypoechoic to anechoic) and a clearly visible uterine horns lumen which had decreased in diameter from $105.9 \pm 0.9 \mathrm{~mm}$ to $87.2 \pm 4.6 \mathrm{~mm}$. From the $8^{\text {th }}$ day to the $14^{\text {th }}$ day, lumen diameter had decreased from $80.4 \pm 3.8 \mathrm{~mm}$ to $63.6 \pm 3.2 \mathrm{~mm}$. The presence of caruncle was reduced and
\end{abstract}


the amount of lochia was decreased (anechoic). From the $15^{\text {th }}$ day to the $21^{\text {st }}$ day, lumen diameter had decreased from $61.4 \pm 2.1 \mathrm{~mm}$ to $52.1 \pm 2.7 \mathrm{~mm}$, and the remnants of caruncle and lochia were still visible. From the $22^{\text {nd }}$ day to the $26^{\text {th }}$ day, the diameter of the uterine wall had decreased from $49.7 \pm 0.6 \mathrm{~mm}$ to $41.5 \pm 6.7 \mathrm{~mm}$, and the lochia and caruncle were no longer visible. From the $26^{\text {th }}$ to the $30^{\text {th }}$ day, uterine horns lumen diameter had still decreased from $41.5 \pm 6.7 \mathrm{~mm}$ to $31.7 \pm 0.9 \mathrm{~mm}$. Uterine horns lumen diameter size had decreased every day, stabilized on the $30^{\text {th }}$ day, and ceased to decrease on the $31^{\text {st }}$ day, where the diameter size was the same as on the $30^{\text {th }}$ day postpartum $(31.7 \pm 0.9 \mathrm{~mm})$. It can be concluded that the duration of uterine involution in PE goats, which had normal delivery is $30-31$ days.

Key words: PE goat; ultrasonography; uterine involution

\section{Introduction}

Postpartum uterine involution has a profound effect on reproductive and economic interests in order to determine the optimal timing of subsequent pregnancies ${ }^{1}$ (Sanchez et al., 2002). During the postpartum period, the reproductive system returns to normal function and prepares itself for a new pregnancy (Elsheikh et al., 2013). Uterine involution is the reduction of uterine volume from pregnancy size to normal size of the uterus before pregnancy. In this reduction process, the following processes also occur: regeneration of the endometrial epithelium, reduction of myometrial tendon fibers, and reduction of uterine blood vessels. The maternal placenta experiences involution through necrosis of caruncle cord due to vasoconstriction, leukocyte infiltration and caruncle removal due to fat infiltration, dissolution, drainage and decay of the entire caruncle surface that becomes lochia (Gier and Marion, 1968). Uterine involution is needed to prepare for a new pregnancy. The time needed to complete the uterine involution macroscopically in sheep varies between 17-30 days (Van Wyck et al., 1972), whereas uterine involution in Kacang goat (Capra hircus) is completed on the 20th day, which is marked by the stabilization in size of the diameter of uterine horns lumen (Riady et al., 2015).

According to Call et al. (1976), it is difficult to assess the time of uterine involution in goats, because the uterus cannot be examined by rectal palpation. Most studies of uterine involution were examined surgically or by laparotomy ${ }^{7}$ (Rubianes et al., 1996). According to Goel and Agrawal (1992), several techniques such as laparotomy, laparoscopy, and radiography, which were used to study various stages and changes in uterine morphology in ruminants, had many disadvantages. Its application in this field has surgical risks, radiation hazards, requires certain expertise or specific laboratory requirements. The dynamic aspects of morphological changes are largely inaccessible, while ultrasound provides non-invasive techniques that do not interfere with organs (Griffin and Ginther, 1992). Ultrasound is routinely used for the diagnosis of pregnancy in goats (Buckrell, 1988). Examination of pregnancy with ultrasound can be carried out in two different methods, namely transrectal and transcutaneous, depending on the method of diagnosis, type of ultrasound probe available, and conditions on the ground at the time of examination (Kahn, 2004). In addition, Hauser and Bostedt (2002) proved that transrectal ultrasonography was a useful and reliable method for observing uterine involution in sheep.

This study aimed to describe the uterine involution of Etawa crossbreed (PE) goat using transcutaneous ultrasonography. The benefit of this study was expected to provide information about the description of uterine involution of Etawa crossbreed (PE) goats.

\section{Materials and Methods}

This study used four postpartum female goats which delivered their placenta normally. Female goats were kept in separate cages with male goats and were allowed to breastfeed their lambs. Observations were made using ultrasound (DP3300 MINDRAY, Shenzen Mindray BioMedical Electronic Co. Ltd, China) with $3.5 \mathrm{MHz}$ abdominal probes (35C50EB, Shenzen Mindray Bio-Medical Electronic Co. Ltd, China) in PE goats since the first day of postpartum period. Observation of uterine involution stopped after 
there was no longer a reduction in the diameter of uterine lumen.

\section{Observation of Uterine Involution with Transcutaneous Ultrasound}

Observation of uterine involution using transcutaneous ultrasound started from the first day of postpartum period. Goat were observed at the same hour every day. For the initial step, an ultrasound device was prepared, then the ultrasound was placed to the left of the operator's arm and the operator was on the left side of the goat. Observation of uterine involution using transcutaneous ultrasound was performed after the goat was laid in a lateral recumbence position. Some hair in the abdominal area was shaved before the evaluation in order to acquire the best visualization of the image in this area.

The next step was the application of KY jelly around the abdomen. The probe was gently pressed on the abdomen towards urinary bladder, then it was directed to cranially to the mammary glands and to the base of the hind leg. Afterwards, the ultrasound device was directed to the dorsal and slightly caudomedial, followed by measurement of the lumen diameter of the uterine horns. Ultrasound images were taken with the freeze button and then the diameter of uterine horns lumen was measured. After the observation was completed, the abdomen was cleaned of the excess KY jelly. Observation was stopped and involution was said to be complete after there was no longer a reduction in uterine lumen diameter.

\section{Data Analysis}

The results of observation of uterine involution were analyzed descriptively and presented in several images.

\section{Results and Discussion}

On the first day until the $7^{\text {th }}$ day of postpartum period, the uterine horns images were almost identical, and the diameter of the uterine horns lumen consistently decreased every day from $105.9 \pm 0.9 \mathrm{~mm}$ to $87.2 \pm 4.6 \mathrm{~mm}$. Examination of postpartum uterus on the first day clearly showed the caruncle, the uterine lumen, and the uterine wall appearances. The appearance of caruncles on the uterine wall from ultrasound examination was hypoechoic (gray), while the lumen of the uterus, which was filled with lochia was hypoechoic to anechoic (Figure 1).

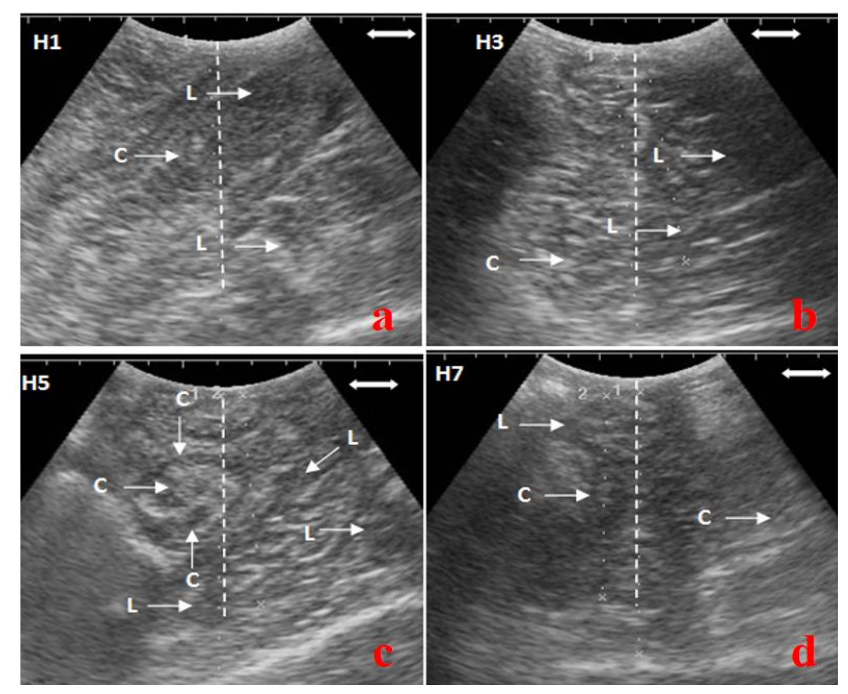

Figure 1. Transcutaneous ultrasound features of uterine involution of PE goats on the first day until the 7th day of postpartum period. The uterine lumen was filled with lochia and caruncles were still clearly visible (a. day 1 , b. day 3, c. day 5, d. day 7, $\mathrm{L}=$ lochia, $\mathrm{C}=$ caruncle, $\mathrm{H}$ = day). (Bar scale: $50 \mathrm{~mm}$.)

These ultrasound images of postpartum uterine (H-1 to H-7) in PE goats were almost the same as images which were reported by Riady et al. (2015) in Kacang goats. The images showed that caruncle was hypoechoic and anechoic in the center, lochia was anechoic, and the blood vessel layer was anechoic which limits the endometrium (hypoechoic) to the myometrium (hypoechoic). According to Ababneh and Degefa (2005) in Balady goats, observation of uterine involution using transcutaneous ultrasound on the first and second days of postpartum period showed caruncles, myometrial and endometrial layers separated clearly by anechoic lines, and anechoic lochia in the uterine lumen.

Uterine involution occurs on a reduced logarithmic scale with the most significant changes occurs during the first days postpartum. Uterine contractions last for several days, during which the amount of lochia is reduced and followed by a reduction of the uterine lumen (Noakes, 2009). This finding was supported by a study by Degefa et al. (2006) which found that uterine involution in Balady goats was divided into three stages: the 
most rapid decline occurred until the $7^{\text {th }}$ day, the regression stage occurred until the $13^{\text {th }}$ day, and uterine involution was completed on the $19^{\text {th }}$ day of postpartum period. The results of a study by Ababneh and Degefa (2005) also proved that the decrease in uterine volume was significantly faster until the $7^{\text {th }}$ day of postpartum period compared to the $7^{\text {th }}$ to $19^{\text {th }}$ day of postpartum period. According to Hauser and Bostedt (2002), uterine regression is completed around 17-19 days postpartum based on a research conducted on sheep.

The diameter of uterine horns lumen on the $8^{\text {th }}$ day was $80.4 \pm 3.8 \mathrm{~mm}$, which was decreased daily to $63.6 \pm 3.2 \mathrm{~mm}$ on the $14^{\text {th }}$ day of postpartum period as presented in Figure 2. Hauser and Bostedt (2002) also stated that ultrasound could accurately distinguish and measure the caruncles only until the $8^{\text {th }}$ day of postpartum period. Fasulkov (2012) stated that on the $9^{\text {th }}$ day of postpartum period, only the thickness of the uterine wall that could be measured using transcutaneous ultrasound. Uterine involution in small ruminants were characterized by a reduction in the size and the presence of rapid uterine contractions as showed by measurements of uterine weight and length, lumen diameter, and diameter of uterine horns of pregnant animals (Noakes, 2009).
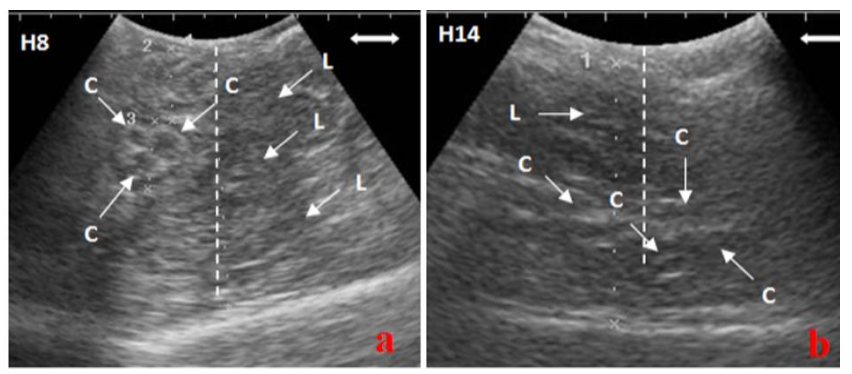

Figure 2. Transcutaneous ultrasound features of uterine involution of PE goats on the $8^{\text {th }}$ and the $14^{\text {th }}$ day of postpartum period. The appearance of the caruncle was diminished and the lochia began to thin out which was shown by anechoic appearance (a. day $8, \mathrm{~b}$. day $14, \mathrm{~L}=$ lochia, $\mathrm{C}$ = caruncle, $\mathrm{H}=$ Day). (Bar scale: $50 \mathrm{~mm}$.).

From the $15^{\text {th }}$ to the $21^{\text {st }}$ day, ultrasound images showed that the lumen of the uterine horns, the remnants of caruncle, and the lochia began to become less obvious by the $21^{\text {st }}$ day. The diameter of uterine horns lumen on the $15^{\text {th }}$ day was $61.4 \pm 2.1$ $\mathrm{mm}$ which had decreased to a size of $52.1 \pm 2.7 \mathrm{~mm}$ by the $21^{\text {st }}$ day, as presented in Figure 3. In this study, the images only showed two layers of the uterus namely the endometrium and myometrium while the perimetrium layer was not seen. Hauser and Bostedt (2002) reported that perimetrium and myometrium exhibit the same echoic structure (image) so it was impossible to distinguish them from ultrasound observations. The vascular layer, which was located in the myometrial layer, was a sign of high vascularization. This anechoic vascular layer can be seen as a black line in the cross-section.

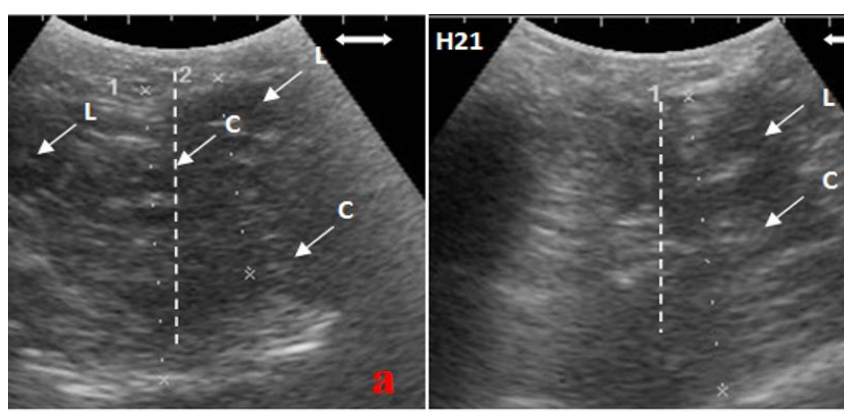

Figure 3. Transcutaneous ultrasound features of uterine involution of PE goats on the $15^{\text {th }}$ and $21^{\text {st }}$ day of postpartum period (a. day $15, \mathrm{~b}$. day $21, \mathrm{~L}=$ lochia, $\mathrm{C}=$ caruncle, $\mathrm{H}=$ Day). (Bar scale: $50 \mathrm{~mm}$.)

Observation of uterine involution on the $22^{\text {nd }}$ day of postpartum showed that lochia in the lumen of the uterus was no longer visible. The average diameter of uterine horns lumen on the $22^{\text {nd }}$ day was $49.7 \pm 0.6 \mathrm{~mm}$ and it had decreased to $41.5 \pm 6.7$ $\mathrm{mm}$ by the $26^{\text {th }}$ day of postpartum period and the lochia or caruncles were no longer visible (Figure 4).

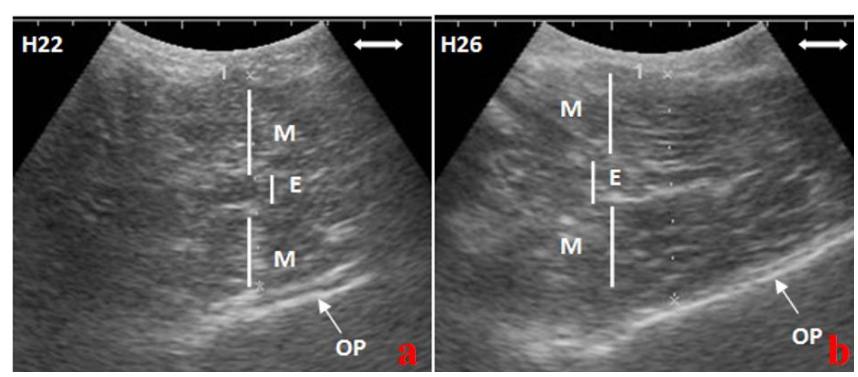

Figure 4. Transcutaneous ultrasound features of uterine involution of PE goats on the $22^{\text {nd }}$ and $26^{\text {th }}$ day of postpartum period (a. day 22, b. day 26, $\mathrm{E}=$ Endometrium, $\mathrm{M}=$ Myometrium, $\mathrm{OP}=$ Os Pubis, $\mathrm{H}=$ Day). (Bar scale: 50 $\mathrm{mm}$.)

After the offspring is born, the uterus, which experiences contraction and retraction during pregnancy, becomes hard so it could close large blood vessels, which lead to placental implantation site (Sarwono, 2002). Uterine involution is an 
autolysis process or a self-destruction process that occurs in the uterine muscle, the tissue, which undergoes proliferation in the presence of large amounts of estrogen. It then undergoes atrophy as a response to the cessation of estrogen production, which accompanies the release of the placenta. The effect of oxytocin hormone release from pituitary gland strengthens and regulates uterine contractions, compresses blood vessels, and helps the hemostasis process. The contraction and retraction of uterine muscle reduces the blood supply to the uterus. This process helps reduce the scar where the placenta was implanted and reduces bleeding (Sarwono, 2008).

Uterine involution is highly dependent on myometrial contraction, bacterial elimination, and regression of the endometrium. These three things are related to each other. The myometrium is a collection of smooth muscle cells and collagen fibers that will contract regularly under the influence of the estrogen, prostaglandin, and oxytocin hormones during postpartum period. This process results in shortening of longitudinal and circular myometrial fibers, followed by involution of caruncle and endometrial regeneration. Factors that influence uterine involution are breastfeeding, quality and quantity of feed, and hormonal activity. The longer the period of breastfeed, the lower the quality and quantity of feed. Additionally, the lack of hormonal stimulation, especially prostaglandins, prolongs uterine involution and consequently the interval of breeding will be longer (Jainudeen and Hafez, 1993).

From the $26^{\text {th }}$ to the $30^{\text {th }}$ day, the ultrasound images of the uterus only show the lumen of the uterine horns, whereas the caruncle, uterine wall layer, vascular layer, and lochia were not seen. The average diameter of uterine horns lumen on the $26^{\text {th }}$ day was $41.5 \pm 6.7 \mathrm{~mm}$, which had decreased to $31.7 \pm 0.9 \mathrm{~mm}$ by the $30^{\text {th }}$ day. On the $30^{\text {th }}$ and $31^{\text {st }}$ day of postpartum period, the diameter of the uterus lumen remained at $31.7 \pm 0.9 \mathrm{~mm}$ and the observation of uterine involution was stopped. This was in accordance with a study by Ababneh and Defega (2005), which found that in Balady goat, involution was completed after there was no longer reduction in the diameter of the uterine horns lumen. Uterine ultrasound features of PE goats on the $30^{\text {th }}$ and $31^{\text {st }}$ day are shown in Figure 5.
Endometrial and myometrial features were poorly differentiated using transcutaneous ultrasound because the diameter of uterine is fixed, same as before pregnant. This imaging is different from the appearance of a pregnant goat uterine. In previous research Melia et al. (2018) reported, the uterus of non-pregnant Etawa crossbred goat showed isoechogenic uterus lumen, no hypoechogenic appearance from embryonic vesicle and no image of isoechogenic embryo as early indication of diagnosing pregnancy.

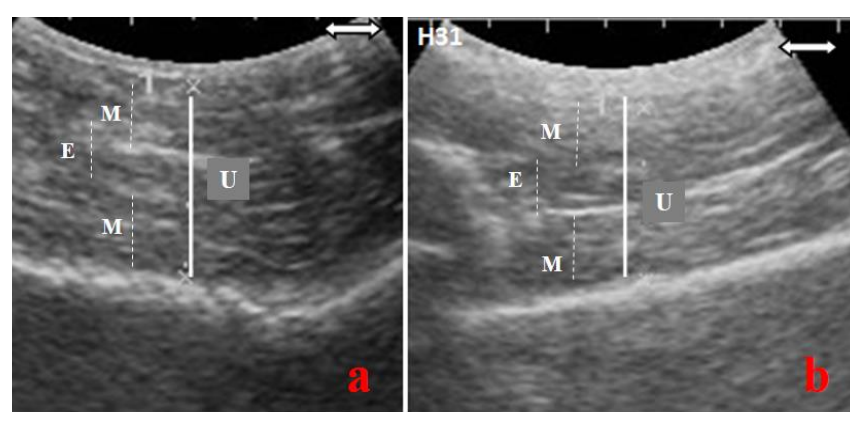

Figure 5. Transcutaneous ultrasound features of uterine involution of PE goats on the $30^{\text {th }}$ and $31^{\text {st }}$ day of postpartum period. (a. day 30 , b. day $31, \mathrm{U}=$ uterine, $\mathrm{M}=$ myometrium, $\mathrm{E}=$ endometrium, $\mathrm{H}=$ Day). (Bar scale: $50 \mathrm{~mm}$.)

The time required for uterine involution varies according to the type of animal, reproductive status, and time of observation (Jainudeen and Hafez, 1993). Most of the studies found that uterine involution is completed around 17-19 days postpartum (Hauser and Bostedt, 2002; Ababneh and Degefa, 2005). In Kacang goats, uterine involution is completed on the $20^{\text {th }}$ day of postpartum with a diameter of $19.3 \mathrm{~mm}^{5}$. Another technique used to observe the process of uterine involution in small ruminants is the measurement of hormone and its metabolites, radiography, and laparotomy. In this study, there were three goats with single gestation and one goat with multiple gestations. The measurements of uterine horns diameter and the duration to complete uterine involution were similar in goats with multiple gestation and single gestation.

\section{Conclusion}

Ultrasonography of uterine involution in PE goats showed caruncles and lochia were present until the $21^{\text {st }}$ day of postpartum period. There was a daily decrease in the diameter of the uterine 
horns lumen from $105.9 \pm 0.9 \mathrm{~mm}$ on the first day to $31.7 \pm 0.9 \mathrm{~mm}$ on the $31^{\text {st }}$ day of postpartum period. The process of uterine involution in $\mathrm{PE}$ goats, which had normal delivery lasted for 30-31 days.

\section{Conflict of Interests}

The authors have no conflict of interests.

\section{Acknowledgment}

The author would like to express gratitude the Directorate of Research and Community Service, Directorate General of Research, Technology, and Higher Education Empowerment, Ministry of Research, Technology, and Higher Education which provided grant for this research through Competitive Research Grant Number: 025 / SP2H / LT / DRPM / II / 2016, dated February 17 ${ }^{\text {th }}, 2016$, and UD. Thanks also to Puna Farm Lamduro Aceh Besar, which helped conduct this study.

\section{References}

Ababneh M and Defega T (2005). Ultrasonic assessment of puerperal uterine involution in Balady goats. Journal of Veterinary Medical Association, 52(5): 244-248.

Buckrell BC (1988). Applications of ultrasonography in reproduction in sheep and goats. Theriogenology, 29(1): 71-84.

Call JW, Foote WC, Eckre CD and Hulet CV (1976). Postpartum uterine and ovarian changes and estrous behaviour from lactation effects in normal and hormone treated ewes. Theriogenology, 6(5): 495-521.

Degefa T, Ababneh MM and Moustafa MF (2006). Uterine involution in the post-partum Balady goat. Veterinarski Archiv. 76(2): 119-133.

Elsheikh AS, Omer NNE and Alqurashi AM (2013). Management of postpartum interval of Nubian goats with PGF2 $\alpha$ and GnRH. Journal of American Science, 9(3): 181184.

Fasulkov I (2012). Ultrasonography of uterine involution in goats. Istanbul Universitesi Veteriner Fakultesi Dergisi, 40(1): 63-69.
Gier HT and Marion GB (1968). Uterus of the cow after parturition: Involutional changes. American Journal of Veterinary Research, 29(1): 83-96.

Goel AK and Agrawal KP (1992). A review of pregnancy diagnosis techniques in sheep and goats. Small Ruminant Research, 9(3): 255-264.

Griffin PG and Ginther OJ (1992). Research applications of ultrasonic imaging in reproductive biology. Journal of Animal Science, 70(3): 953-972.

Hauser B and Bostedt H (2002). Ultrasonographic observation of the uterine regression in the ewe under different obstetrical conditions. Journal of Veterinary Medical Association, 49(10): 511-516.

Ishwar AK (1995). Pregnancy diagnosis in sheep and goats: A review. Small Rumininant Research, 17(1): 37-44.

Jainudeen MR and Hafez ESE (1993). Sheep and goat. In Hafez ESE 1993. Reproduction in Farm Animals. $6^{\text {nd }}$ ed., Lea and Febiger, Philadelphia: 330-342.

Kahn W (2004). Veterinary reproductive ultrasonography. Schlutersche Verlacsgesse lschaft Mbh \& Co., Hannover: 113-217.

Kene ROC (1991). Radiographic investigation of dystocia in the West Africa Dwarf Goat. British Veterinary Journal, 17(3): 283-289.

Melia J, Fauziah, Hamdan, Panjaitan B, Syafruddin, Armansyah T and Siregar TN (2018). The image of embryo and fetal of etawa crossbred goats using ultrasonography at different gestational ages. J. Ked. Hewan. 12(2): 47-52.

Noakes DE (2009). The puerperium. In Veterinary Reproduction and Obstetrics. Noakes DE, Parkinson TJ and England GCW (Eds). 9 $^{\text {th }}$ ed. W.B. Saunders, Philadelphia: 137-149.

Riady G, Siregar TN, Melia J, Hamdan and Ayunanda R (2015). Gambaran involusi uterus kambing kacang (Capra sp.) berdasarkan pengamatan dengan ultrasonografi transkutaneus. Jurnal Kedokteran Hewan, 9(1): 24-28. 
Rubianes E, Ungerfeld R, Vinoles C, Carbajal B, de-Castro T and Ibarra D (1996). Uterine involution time and ovarian activity in weaned and suckling ewes. Canada Journal of Animal Science, 76(1): 153-155.

Sanchez MA, Garcia P, Menendez S, Sanchez B, Gonzalez M and Flores JM (2002) Fibroblastic growth factor receptor (FGF-R) expression during uterine involution in goat. Animal of Reproduction Science, 69(1-2): 25-35.

Sarwono P (2008). Ilmu kebidanan. Bina Pustaka, Jakarta: 45-59.
Tian W and Noakes DE (1991). A radiographic methods for measuring the effect of exogenous hormone therapy on uterine involution in ewes. Veterinary Record, 129(21): pp. 463-466.

Van Wyck LC, Van Niekerk $\mathrm{CH}$ and Bolonje PC (1972). Involution of the postpartum uterus of the ewe. Journal of South African Veterinary Association, 43(1): 19-26. 